\title{
Schiff Base and Its Fe(II), Zn(II), Ru(II), Pd(II) Complexes Containing ONS Donor Atoms: Synthesis, characterization and Catalytic Studies
}

\author{
ONS Donor Atomları İçeren Schiff Bazı ve Fe(II), Zn(II), \\ Ru(II), Pd(II) Kompleksleri: Sentez, Karakterizasyon ve \\ Katalitik Calıșmalar
}

\author{
Kenan Buldurun ${ }^{1 *}$, Nevin Turan ${ }^{1^{*}} \oplus$, Naki Çolak ${ }^{2} \oplus$, İsmail Özdemir ${ }^{3}(\mathbb{0}$ \\ ${ }^{1}$ Muş Alparslan University, Faculty of Arts and Sciences, Chemistry Department, Muș, TURKEY \\ ${ }^{2}$ Hitit University, Faculty of Arts and Sciences, Chemistry Department, Çorum, TURKEY \\ 3Inönü University, Catalysis Research and Application Center, Malatya, TURKEY \\ Sorumlu Yazarlar / Corresponding Authors*: k.buldurun@alparslan.edu.tr, n.turan@alparslan.edu.tr \\ Geliş Tarihi /Received: 07.03.2018 \\ DOI:10.21205/deufmd.2019216108 \\ Kabul Tarihi / Accepted: 30.07 .2018 \\ Araștırma Makalesi/Research Article \\ Atıf sekli/How to cite: BULDURUN, K., TURAN, N., COLAK, N., ÖZDEMIR, I. (2019). Schiff Base and Its Fe(II), Zn(II), Ru(II), Pd(II) Complexes \\ Containing ONS Donor Atoms: Synthesis, characterization and Catalytic Studies. DEUFMD, 21(61), 73-82.
}

\begin{abstract}
The work include the synthesis, spectroscopic characterization and as well as catalytic activities of Fe(II), Zn(II), Ru(II), and Pd(II) complexes with a novel Schiff base ligand derived from methyl 2amino-5,5,7,7-tetramethyl-4,5,6,7-tetrahydrobenzo[b]thiophene-3-carboxylate and salicylaldehyde. Spectroscopic techniques including IR, UV-Vis, NMR, and mass analysis as well as elemental analysis and magnetic susceptibility measurement were used to identify the compounds. Based on elemental and spectral studies octahedral geometry was proposed to Fe(II), $\mathrm{Zn}$ (II) and $\mathrm{Ru}(\mathrm{II})$ complexes and square planar geometry was proposed to $\mathrm{Pd}(\mathrm{II})$ complex. To improve more efficient and stable catalysts, we wanted to study if there is any influence the catalytic activity of ruthenium complex for the transfer hydrogenation of ketones and we wanted to examine the catalytic activities of palladium complex in Suzuki C-C cross coupling reactions under various conditions.

Keywords: Suzuki coupling, Metal complexes, Carboxylate, Spectroscopic techniques

Öz

Bu çalıșma metil 2-amino-5,5,7,7-tetrametil-4,5,6,7-tetrahidrobenzo[b]tiyofen-3-karboksilat ve salisilaldehitten elde edilen yeni bir Schiff bazı ligandı ile $\mathrm{Fe}(\mathrm{II}), \mathrm{Zn}(\mathrm{II}), \mathrm{Ru}(\mathrm{II})$ ve $\mathrm{Pd}(\mathrm{II})$ komplekslerinin sentez, spektroskopik karakterizasyon ilaveten katalitik aktivitelerini içermektedir. Bileşikleri tanımlamak için element analiz ve manyetik süsseptibilite ölçümü dâhil olmak üzere IR, UV-Vis, NMR ve kütle analizi içeren spektroskopik teknikler kullanıldı. Elemental ve spektral çalışmalara dayanarak, Fe(II), Zn(II) ve Ru(II) komplekslerine oktahedral geometri ve Pd (II) kompleksine kare düzlem geometri önerildi. Daha etkili ve kararlı katalizörler geliştirmek için, rutenyum kompleksinin ketonların hidrojen transferindeki katalitik aktiviteyi etkileyip etkilemediğini ve paladyum kompleksinin çeşitli koşullar altında Suzuki C-C çapraz eşleşme tepkimelerindeki katalitik aktivitelerini incelemek istedik.
\end{abstract}

Anahtar Kelimeler: Suzuki eșleșme, Metal kompleksler, Karboksilat, Spektroskopik teknikler 


\section{Introduction}

Schiff bases derived from substituted salicylaldehydes and various amines and their metal complexes have been widely investigated due to their wide applicability [1]. The applications of Schiff bases and transition metal complexes have been extensively studied in biochemistry $[3,4]$, catalysis [5] medicinal, industrial [6], pharmaceutical [7] and analytical applications $[8,9]$. Since the first report of their metal complexes, simple di-, ter-, and tetraSchiff base ligands have been extensively studied and used for the metal complexation. Extension of the study to include bidentate NO and tridentate ONP or ONS donor sets is capable of providing multi-choice coordination types, and it has been accordingly understood that a few polynuclear complexes bearing Schiff-base ligands are abundant in the literature, owing to the case that they can be modified by various functional groups [10].

Many Schiff base complexes of metal ions show high catalytic activity and played a significant role in various reactions to enhance their yield and product selectivity. The convenient route of synthesis and thermal stability of Schiff base ligands have contributed significantly for their possible applications in catalysis as metal complexes [11].

Recently, the palladium-catalyzed cross-linking reaction for the formation of carbon-carbon bonds has emerged as a powerful method in an organic synthesis [12]. In particular, the SuzukiMiyaura coupling reaction, which is referred to as cross-coupling of palladium-catalyzed organic halides with arylboronicacids, is one of the most effective methods for forming $\mathrm{C}-\mathrm{C}$ bonds [13]. The products obtained in these reactions have been taken into account for their high prevalence in a wide variety of fields, including industrial, for the pharmaceutical, polymer, liquid crystals, agricultural chemical industries [14-16]. They are also used as natural products, molecular organic materials and components for optical device production $[17,18]$. Until now, soluble palladium(II) complexes with various ligands such as oxazolines, thioureas, pyridines, pyrazoles [19], imidazole [20], Schiff bases [21,22] and Nheterocyclic carbines [23] have been used as effective catalysts. Among these ligands, Schiff base ligands have superior properties such as ease of obtaining, low cost, thermal and chemical stability [24]. Ruthenium(II) complexes containing arene are usually the most important catalysts used in the transfer hydrogenation of ketones [25].

In view of above, we thought it was worthwhile to synthesis salicylaldehyde with thiophene moiety. In the present study, we describe synthesis of (E)-methyl2-(2-hydroxy benzylideneamino)-5,5,7,7-tetramethyl -4,5,6,7tetrahydrobenzo $[b]$ thiophene-3-carboxylate $(\mathrm{L})$ and its complexes and characterization by elemental analysis, UV-Vis, IR, ${ }^{1} \mathrm{H},{ }^{13} \mathrm{C}$ NMR, mass analysis, magnetic susceptibility. The catalytic activities of $\mathrm{Ru}(\mathrm{II})$ and $\mathrm{Pd}(\mathrm{II})$ complexes were also reported.

\section{Material ve Method}

All the chemicals used were of reagent grade. Solvents were purified and distilled for synthesis and physical measurements. The IR spectra were recorded in $\mathrm{KBr}$ discs in the wave number range of $4000-400 \mathrm{~cm}^{-1}$ on a Perkin Elmer Model 65 FTIR Spectrophotometer. The ${ }^{1} \mathrm{H},{ }^{13} \mathrm{C}$ NMR spectra were recorded in $\mathrm{CDCl}_{3}$ solvent respectively on Perkin Elmer $400 \mathrm{MHz}$ NMR spectrometer using tetramethylsilane as the internal standard. Chemical shifts have been expressed in ppm. Electronic spectra were recorded on a UV-visible Shimadzu1800 in the wavelength 1100-190 $\mathrm{nm}$. Mass spectra were recorded on Varian Inc, Anadolu University made Liquid Chromatography Mass Spectrometer. Elemental analyses (carbon, hydrogen, nitrogen and sulfur) were performed on a LECO 932 CHNS analyzer. Magnetic susceptibility measurements were carried out using $\mathrm{Hg}\left[\mathrm{Co}(\mathrm{SCN})_{4}\right]$ as calibrant by Gouy balance.

\subsection{Synthesis and characterization of ligand and complexes}

Ligand was prepared using standard procedures involving the condensation of methyl 2-amino-5,5,7,7-tetramethyl-4,5,6,7tetrahydrobenzo[ $b]$ thiophene-3-carboxylate $(0.95 \mathrm{~g}, 0.004 \mathrm{mmol})$ and with salicylaldehyde $(0.45 \mathrm{~g}, 0.004 \mathrm{mmol})$ in absolute ethanol (50 $\mathrm{mL}$ ) in the presence of a few drops of glacial acetic acid. The mixture was stirred at reflux for $24 \mathrm{~h}$. By slow cooling of the reaction mixture room temperature, a light brown crystal of Schiff base ligand was obtained. 


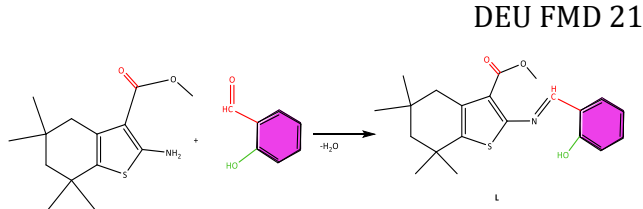

Figure 1. Structural representation of the Schiff base ligand

Ligand-Empirical formula: $\left(\mathrm{C}_{21} \mathrm{H}_{25} \mathrm{NO}_{3} \mathrm{~S}\right)$; formula weight: $371.49 \mathrm{~g} / \mathrm{mol}$; yield: $\% 72$; FTIR (KBr, $v$ max $\left.\left(\mathrm{cm}^{-1}\right)\right): 3346(-\mathrm{OH}), 3000(\mathrm{Ar}-$ $\mathrm{CH}$ ), 2903, 2831 (Aliph.-CH, $\left.\mathrm{CH}_{3}\right), 1731(\mathrm{C}=0)$, $1602(\mathrm{CH}=\mathrm{N}), 1586,1515(\mathrm{Ar}-\mathrm{C}=\mathrm{C}), 1157(\mathrm{C}-\mathrm{O})$, 759 (C-S-C); ${ }^{1} \mathrm{H}-\mathrm{NMR}\left(400 \mathrm{Mz}, \mathrm{CDCl}_{3}\right): \delta(\mathrm{ppm})$ $=11.20(\mathrm{~s}, \mathrm{H}, \mathrm{OH}), 8.70(\mathrm{~s}, \mathrm{H}, \mathrm{N}=\mathrm{CH}), 7.60-7.00$ (m, 4H, Ar-H), 3.39 (s, 3H, $\left.-\mathrm{CO}-\mathrm{O}-\mathrm{CH}_{3}\right), 2.40-$ 1.40 (s, $4 \mathrm{H}$, cyclohexane), $1.40-0.98(\mathrm{~s}, 12 \mathrm{H}$, $\left.4 \mathrm{CH}_{3}\right) ;{ }^{13} \mathrm{C}-\mathrm{NMR}\left(400 \mathrm{MHz}, \mathrm{CDCl}_{3}\right): \delta(\mathrm{ppm})=$ $159.00(\mathrm{C}=\mathrm{O}), 160.00(\mathrm{CH}=\mathrm{N}), 150.30-128.60$ (Cthiophene), 161.10-117.80 (Cbenzen), 51.50 (O$\left.\mathrm{CH}_{3}\right), 25.50-41.80$ (C cyclohexane), 30.38-28.68 ($\mathrm{CH}_{3}$ ). Elem. analysis: calc. C, 67.83; $\mathrm{H}, 6.72 ; \mathrm{N}$, 3.76; S, 8.61. Found: $\mathrm{C}, 67.88 ; \mathrm{H}, 6.80 ; \mathrm{N}, 3.75 ; \mathrm{S}$, 8.63; UV-vis bands $\left(\lambda_{\max }, \mathrm{nm},\left(\varepsilon, \mathrm{M}^{-1} \mathrm{~cm}^{-1}\right)\right.$ : $\pi \rightarrow \pi^{*}, 216$ (2000), 257 (2000); $n \rightarrow \pi^{*}, 391$ (735.50). Color: Light brown.

A solution of ligand ( $0.74 \mathrm{~g}, 2 \mathrm{mmol})$ in $30 \mathrm{~mL}$ absolute ethanol was added to metal salts (1 mmol) namely, $\mathrm{ZnCI}_{2}$, and $\mathrm{FeCI}_{2} \cdot 6 \mathrm{H}_{2} \mathrm{O}$. The reaction mixture was refluxed for $18 \mathrm{~h}$. The obtained colored solution was left standing at room temperature to crystallize. The product was removed by filtration, washed with cooled absolute ethanol, recrystallized from dichloromethane/ether mixture (1:1) and dried under vacuum. The analytical and physical data of the complexes are:

$\left[\mathrm{ZnL}_{2}{ }_{2} \cdot 2 \mathrm{H}_{2} \mathrm{O}\right] \cdot 2 \mathrm{H}_{2} \mathrm{O}$-Empirical formula: $\left(\mathrm{C}_{42} \mathrm{H}_{56} \mathrm{~N}_{2} \mathrm{~S}_{2} \mathrm{O}_{10} \mathrm{Zn}\right)$; formula weight: 877.37 g/mol; yield: \%86; FT-IR ( $\left.\mathrm{KBr}, v \max \left(\mathrm{cm}^{-1}\right)\right)$ : 3533, $3483(\mathrm{OH}), 3000$ (Ar-CH), 2956, 2869 (Alift.-CH, $\left.\mathrm{CH}_{3}\right), 1731(\mathrm{C}=0), 1610(\mathrm{CH}=\mathrm{N})$, 1547 ( $\mathrm{Ar}-\mathrm{C}=\mathrm{C}), 1177$ (C-O), 760 (C-S-C), 556, $523(\mathrm{M}-0), 499,461(\mathrm{M}-\mathrm{N})$; Elem. analysis: calc. C, 57.44; H, 6.38; N, 3.19; S, 7.29. Found: C, 57.47; H, 6.45; N, 3.19; S, 7.30; UV-vis bands $\left(\lambda_{\max }, \mathrm{nm},\left(\varepsilon, \mathrm{M}^{-1} \mathrm{~cm}^{-1}\right): \pi \rightarrow \pi^{*}, 237\right.$ (72.40), 340 (55.700), L $\rightarrow$ M, 963 (150); MS [ES]: m/z 875.37 (calcd.), 875.00 (found) [M-2H] ${ }^{-2}$; Color: Orange.

[FeL $\left.{ }^{1}{ }_{2} \cdot 2 \mathrm{H}_{2} \mathrm{O}\right] \cdot \mathrm{H}_{2} \mathrm{O}$-Empirical formula: $\left(\mathrm{C}_{42} \mathrm{H}_{54} \mathrm{~N}_{2} \mathrm{~S}_{2} \mathrm{O}_{9} \mathrm{Fe}\right)$; formula weight: 849.85 g/mol; yield: \%76; FT-IR ( $\left.\mathrm{KBr}, v \max \left(\mathrm{cm}^{-1}\right)\right)$ : 3445, $3404(\mathrm{OH}), 3005$ (Ar-CH), 2948 (Alip$\mathrm{CH}), 1730(\mathrm{C}=\mathrm{O})_{\text {broad, }} 1611(\mathrm{CH}=\mathrm{N}), 1549(\mathrm{Ar}-$
, 73-82, 2019

$\mathrm{C}=\mathrm{C}$ ), 1118 (C-0), 759 (C-S-C), 503 (M-0), 493, $478(\mathrm{M}-\mathrm{N})$; Elem. analysis: calc. C, 59.30; H, 6.35; N, 3.29; S, 7.53. Found: C, 59.37; H, 6.33; N, 3.27; S, 7.52; UV-vis bands $\left(\lambda_{\max }, \mathrm{nm},\left(\varepsilon, \mathrm{M}^{-1} \mathrm{~cm}^{-}\right.\right.$ 1): $\pi \rightarrow \pi^{*}, 240$ (161.80); $n \rightarrow \pi^{*}, 336$ (90.450), 921 (750); MS [ES]: m/z 850.85 (calcd.), 850.80 (Found) $[\mathrm{M}+\mathrm{H}]^{+}$; Color: Black.

A toluene solution of ligand $(0.02 \mathrm{mmol})$ was mixed with $\left[\mathrm{RuCl}_{2}(p \text {-cymene })\right]_{2}(0.01 \mathrm{mmol})$ keeping metal ligand ratio 1:2. The mixture was refluxed for $4 \mathrm{~h}$. The solid product precipitated on cooling was collected by filtration and washed with diethyl ether and recrystallized from $\mathrm{CH}_{2} \mathrm{Cl}_{2} / \mathrm{Et}_{2} \mathrm{O}$ mixture. Similar synthesis were performed for the $\mathrm{Pd}(\mathrm{II})$ complex using bis(acetonitrile)dichloropalladium(II), $\quad(0.01$ mmol).

[RuL $\left.{ }^{1} \mathrm{Cl}\right] \cdot 2 \mathrm{H}_{2} \mathrm{O}$-Empirical formula: $\left(\mathrm{C}_{31} \mathrm{H}_{42} \mathrm{NSO}_{5} \mathrm{ClRu}\right)$; formula weight: 676.52 $\mathrm{g} / \mathrm{mol}$; yield: \%75; FT-IR $\left(\mathrm{KBr}, \operatorname{vmax}\left(\mathrm{cm}^{-1}\right)\right)$ : 3440 (OH), 3054, 3032 (Ar-CH), 2960, 2925 (Alip-CH), $1731(\mathrm{C}=0), 1594(\mathrm{CH}=\mathrm{N}), 1526(\mathrm{Ar}-$ $\mathrm{C}=\mathrm{C}), 1158$ (C-O), 1365 (Ru-Cl), 759 (C-S-C), 569, $525(\mathrm{M}-0), 459(\mathrm{M}-\mathrm{N})$; Elem. analysis: calc. C, 54.98; H, 6.20; N, 2.06; S, 4.73. Found: C, 54.88; H, 6.19; N, 2.08; S, 4.78; UV-vis bands $\left(\lambda_{\max }, \mathrm{nm},\left(\varepsilon, \mathrm{M}^{-1} \mathrm{~cm}^{-1}\right): \pi \rightarrow \pi^{*}, 235\right.$ (200), 258 (200); $n \rightarrow \pi^{*}, 347$ (200), 374 (200); MS [ES]: m/z 674.52 (calcd.), 674.70 (Found): [M-2H] ${ }^{-2}$; Color: Dark Brown.

[PdL $\left.{ }^{1} 2\right]$-Empirical formula: $\left(\mathrm{C}_{42} \mathrm{H}_{48} \mathrm{~N}_{2} \mathrm{~S}_{2} \mathrm{O}_{6} \mathrm{Pd}\right)$; formula weight: $846.40 \mathrm{~g} / \mathrm{mol}$; yield: $\% 65$; FTIR (KBr, vmax $\left(\mathrm{cm}^{-1}\right)$ ): 3525, $3407(\mathrm{OH}), 3043$, (Ar-CH), 2952, 2857 (Alip-CH), $1731(\mathrm{C}=0)$, $1615(\mathrm{CH}=\mathrm{N}), 1539(\mathrm{Ar}-\mathrm{C}=\mathrm{C}), 1147$ (C-O), 758 (C-S-C), 531 (M-O), $463(\mathrm{M}-\mathrm{N})$; Elem. analysis: calc. C, 59.54; H, 5.67; N, 3.30; S, 7.56. Found: C, 59.57; H, 5.60; N, 3.34; S, 7.58; UV-vis bands $\left(\lambda_{\max }, \mathrm{nm},\left(\varepsilon, \mathrm{M}^{-1} \mathrm{~cm}^{-1}\right): \pi \rightarrow \pi^{*}, 216\right.$ (200); 257 (200); $\rightarrow \pi^{*}, 381$ (73.35); MS [ES]: m/z 845.40 (calcd.), 845.97 (Found) [M-H]; Color: Brown.

\section{Results and Discussion}

$\mathrm{Ru}(\mathrm{II}), \quad \mathrm{Fe}(\mathrm{II}), \quad \mathrm{Zn}(\mathrm{II})$ complexes were synthesized by treating $\mathrm{PdCl}_{2}\left(\mathrm{CH}_{3} \mathrm{CN}\right)_{2}$, $\left[\mathrm{RuCl}_{2}(\mathrm{p} \text {-simen) }]_{2}, \mathrm{FeCl}_{2} \cdot 6 \mathrm{H}_{2} \mathrm{O}, \mathrm{ZnCl}_{2}\right.$, and all the complexes were stable in air. The percentages of carbon, hydrogen nitrogen and sulfur were determined experimentally using CHNS analyzer. The physical and analytical data for the newly synthesized compounds was in good agreement with the proposed molecular formulae (Figure 1,2). 
DEU FMD 21(61), 73-82, 2019

The IR spectrum of ligand showed a characteristic broad band centered in the 3346 $\mathrm{cm}^{-1}$ and a sharp strong absorption at 1602 $\mathrm{cm}^{-1}$, attributable to phenolic $\mathrm{OH}$ and to the $v(\mathrm{CH}=\mathrm{N})$ stretching mode, respectively. In the spectra of complexes, the former band disappeared and the latter was shifted to lower frequencies in the spectra of complexes (1594$1615 \mathrm{~cm}^{-1}$ ), suggesting the coordination of the imine nitrogen and the deprotonated phenolic oxygen atoms to the metal atom [26]. The C-0 stretching vibration to showed that 1177-1118 $\mathrm{cm}^{-1}$ for Fe(II), Pd(II), Ru(II) and Zn(II) metals were bound to the oxygen atom in the phenolate group [27]. In addition, these complexes showed new bands near 569-503 and 499-459 $\mathrm{cm}^{-1}$, which indicates the presence of $v(M-O)$ and $v(M-N)$ respectively. The coordination of azomethine nitrogen atom was further supported by the presence of a new band in the range, 499 and $459 \mathrm{~cm}^{-1}$ were due to $v(\mathrm{M}-\mathrm{N})$ mode [28]. The characteristic bands due to the $v(C-S-C)$ thiophene ring and $v(C=0)$ in ligand compared with the IR spectra of respective complexes were remain almost unshifted. This confirmed the thiophene sulfur and carbonyl oxygen did not coordinate to the metal center in case of all the metal complexes $[29,30]$. In Fe(II), Zn(II) complex, a band in the region 3483-3404 $\mathrm{cm}^{-1}$ observed was assigned to $v(\mathrm{OH})$ of coordinated water, which was confirmed from [31]. These results showed that both $\mathrm{Fe}(\mathrm{II})$ and $\mathrm{Zn}$ (II) complexes contain two hydrate water molecule.

The ${ }^{1} \mathrm{H}$ NMR and ${ }^{13} \mathrm{C}$ NMR spectra of all compounds are consistent with the proposed structures. The $\mathrm{CH}=\mathrm{N}$ and $\mathrm{OH}$ groups protons resonances appeared as singlet peaks at 8.70 and $11.20 \mathrm{ppm}$, respectively. Azometine protons were present in $\mathrm{Pd}(\mathrm{II}), \mathrm{Ru}(\mathrm{II})$ metal complexes which were appearance 8.78-8.75 ppm, respectively according to the substituent attached [32]. No appreciable change was seen in the peak positions corresponding to aromatic protons and cyclohexane protons and methylacetat protons in the complexes. Under complexation of complexes $-\mathrm{OH}$ protons did not appear anymore. After ligand $[\mathrm{Ru}(\mathrm{p}$ cymene) $\mathrm{Cl}_{2}$ ] was attached, the chemical shifts of the protons of $p$-cymene group shifted to the back region $(1.10,2.01,2.60-2.80,6.20 \mathrm{ppm}$, respectively). The ligand-bearing aromatic protons were observed at 7.70 and $7.10 \mathrm{ppm}$.
In the ${ }^{13} \mathrm{C}$ NMR spectrum of ligand, two important signals were observed at 160.00 and $159.00 \mathrm{ppm}$, which are attributed to the imine $(\mathrm{CH}=\mathrm{N})$ and the free carbonyl $(\mathrm{C}=\mathrm{O})$ signals, respectively. After the chemical modification of Schiff base ligand, the free carbonyl signal of ligand disappeared, and a new azomethine signal appeared at $163.40 \mathrm{ppm}$ in the spectrum of complexes. This signal showed the condensation of methyl 2-amino-5,5,7,7tetramethyl-4,5,6,7-tetrahydrobenzo $[b]$ thiophene-3-carboxylate with salicylaldehyde was accomplished.

The electronic spectra of the Schiff base and its complexes were summarized in experimental section. The spectra of the ligand showed banded at about 216-257 $\mathrm{nm}$ and a broad shoulder at $391 \mathrm{~nm}$. The first peak was attributed to $\pi \rightarrow \pi^{*}$ transitions. This band was not significantly affected by chelation. The second band in the spectra of the ligand was assigned to $n \rightarrow \pi^{*}$ transition. This band was disappeared via complexation and a new band attributed to the donation of the lone pairs of the nitrogen atoms of the Schiff base to the metal ion (N-M) appear [33]. In complexes the $\mathrm{d}-\mathrm{d}$ transition could not be observed as it was obscured by strong charge transfer transition. The electronic spectra of the $\mathrm{Zn}(\mathrm{II})$ and Fe(II) complexes in the visible region showed intense absorption at 963-921 nm due to metal-toligand charge transfer (MLCT) transitions in addition to the $\pi-\pi^{*}$ and $n-\pi^{*}$ ligand centered transitions. Pd(II) was diamagnetic, suggesting a square-planar geometry for this complex [34]. The complex of $\mathrm{Zn}$ (II) was diamagnetic. In analogy with those described for complex that NO heteroatom having Schiff bases and according to the characterization data, we proposed an octahedral geometry for the Zn(II) complex [35].

The mass spectra of ligand and its metal complexes revealed the peaks at various posit ions of $\mathrm{m} / \mathrm{z}$ values. The peak at $\mathrm{m} / \mathrm{z} 372.00$ in the mass spectrum of ligand signifies molecular ion peak $[\mathrm{M}+\mathrm{H}]^{+}$. The metal complexes, such as, $\mathrm{Fe}(\mathrm{II}), \mathrm{Zn}(\mathrm{II}), \mathrm{Ru}(\mathrm{II})$ and $\mathrm{Pd}(\mathrm{II})$ deliver respective molecular ion peaks at $\mathrm{m} / \mathrm{z} 850.85$ 875.37, 674.52 and 845.40, which strongly support proposed molecular formula of the complexes. These molecular mass values combined with other spectral studies are essential to generate the structure of the compounds. 
DEU FMD 21(61), 73-82, 2019

Table 1. Catalytic activity for transfer hydrogenation of ketones catalyzed by Ru(II) complex

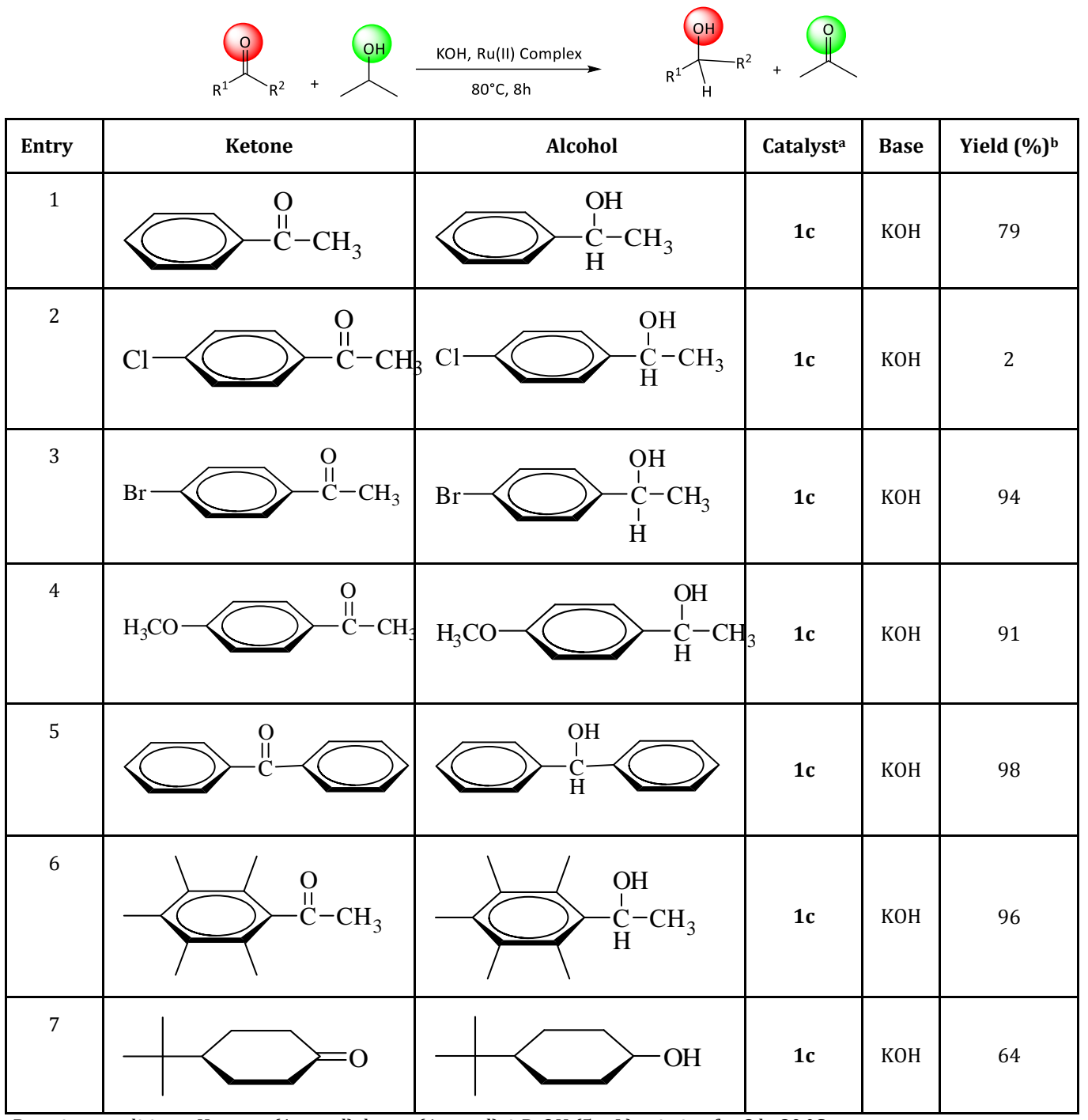

aReaction conditions: Ketones $(1 \mathrm{mmol})$, bases $(4 \mathrm{mmol}), \mathrm{i}-\mathrm{PrOH}(5 \mathrm{~mL})$, stirring for $8 \mathrm{~h}, 80^{\circ} \mathrm{C}$. bYield is determined by GC-MS. 
DEU FMD 21(61), 73-82, 2019

Table 2. Effect of solvents for the Suzuki-Miyaura reaction

\begin{tabular}{|c|c|c|c|c|c|}
\hline Entry & Solvent & Base & $\operatorname{Temp}\left({ }^{\circ} \mathrm{C}\right)$ & Time (hrs) & Conversion \\
\hline 1 & DMF & $\mathrm{NaOH}$ & 100 & 24 & 10 \\
\hline 2 & DMF & $\mathrm{K}_{2} \mathrm{CO}_{3}$ & 100 & 24 & 32 \\
\hline 3 & DMF & $\mathrm{Na}_{2} \mathrm{CO}_{3}$ & 100 & 24 & 17 \\
\hline 4 & DMF & $\mathrm{KOBu}^{\mathrm{t}}$ & 100 & 24 & 12 \\
\hline 5 & Ethanole & $\mathrm{NaOH}$ & 80 & 24 & 52 \\
\hline 6 & Ethanole & $\mathrm{K}_{2} \mathrm{CO}_{3}$ & 80 & 24 & 92 \\
\hline 7 & Ethanole & $\mathrm{Na}_{2} \mathrm{CO}_{3}$ & 80 & 24 & 19 \\
\hline 8 & Ethanole & $\mathrm{KOBu}^{\mathrm{t}}$ & 80 & 24 & 12 \\
\hline 9 & Toluene & $\mathrm{NaOH}$ & 90 & 24 & 15 \\
\hline 10 & Toluene & $\mathrm{K}_{2} \mathrm{CO}_{3}$ & 90 & 24 & 12 \\
\hline 11 & Toluene & $\mathrm{Na}_{2} \mathrm{CO}_{3}$ & 90 & 24 & 20 \\
\hline 12 & Toluene & $\mathrm{KOBu}^{\mathrm{t}}$ & 90 & 24 & 14 \\
\hline 13 & Dioxane & $\mathrm{NaOH}$ & 90 & 24 & 18 \\
\hline 14 & Dioxane & $\mathrm{K}_{2} \mathrm{CO}_{3}$ & 90 & 24 & 48 \\
\hline 15 & Dioxane & $\mathrm{Na}_{2} \mathrm{CO}_{3}$ & 90 & 24 & 32 \\
\hline 16 & Dioxane & $\mathrm{KOBu}^{\mathrm{t}}$ & 90 & 24 & 28 \\
\hline
\end{tabular}

Reaction conditions: 4-Bromoacetophenone $(0.3 \mathrm{mmol})$, phenylboronic acid $(0.45 \mathrm{mmol})$, catalyst $(0.001 \mathrm{mmol})$ and base $(1.5 \mathrm{mmol})$, solvent $(5 \mathrm{~mL})$

Table 3. Yields from Suzuki-Miyaura cross-coupling reactions catalyzed by complex $3 \mathrm{~d}$.

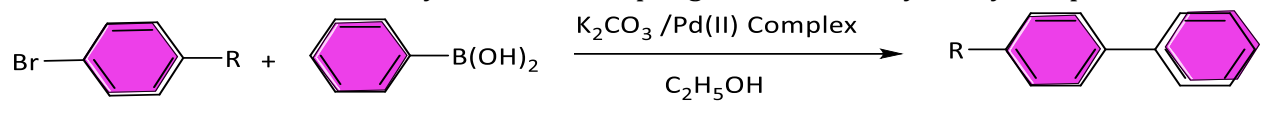

\begin{tabular}{|c|c|c|c|c|}
\hline Entry & Catalysts $^{\mathbf{a}}$ & $\mathbf{R}$ & Time & Yield(\%) $^{\mathbf{b}, \mathbf{c}}$ \\
\hline 1 & $\mathbf{1 d}$ & $-\mathrm{COCH}_{3}$ & 3 & 92 \\
\hline 2 & $\mathbf{1 d}$ & $-\mathrm{CH}_{3}$ & 3 & 79 \\
\hline 3 & $\mathbf{1 d}$ & $-\mathrm{OCH}_{3}$ & 3 & 82 \\
\hline 4 & $\mathbf{1 d}$ & $-\mathrm{H}$ & 3 & 76 \\
\hline 5 & $\mathbf{1 d}$ & $-\mathrm{CHO}$ & 3 & 86 \\
\hline
\end{tabular}

a Reaction conditions: 4-Bromoacetophenone $(0.3 \mathrm{mmol})$, phenylboronic acid $(0.45 \mathrm{mmol})$, catalyst $(0.001 \mathrm{mmol})$ and base ( $1.5 \mathrm{mmol})$, ethanole $(5 \mathrm{~mL})$

b All reactions were monitored by GC-MS.

${ }^{\mathrm{c}}$ Isolated yield (purity of yield checked by NMR). 


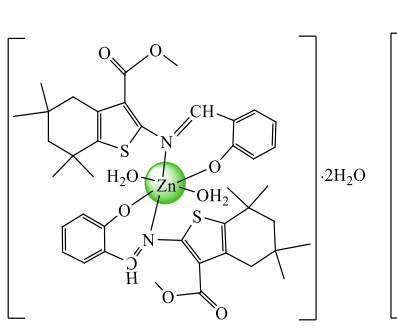

1a

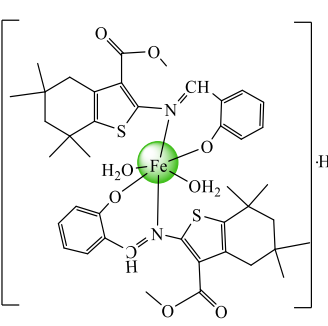

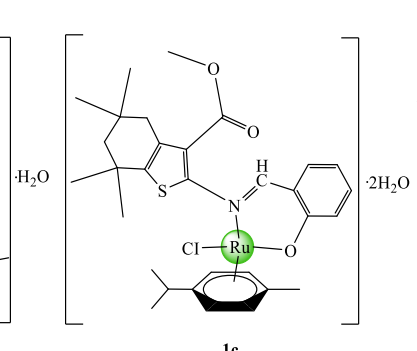

$1 \mathrm{c}$

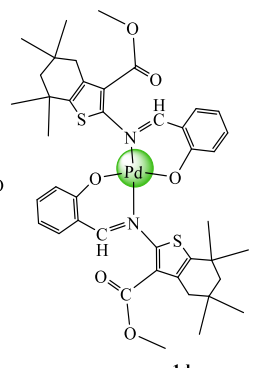

1d

Figure 2. The proposed structure for metal complexes

As the base facilitates the formation of a ruthenium alkoxide by removing the proton from isopropanol, different bases were used as accelerators in the transfer hydrogenation of the ketones (Table 1). Benzophenone was retained as a test substrate and allowed to react with the $\mathrm{Ru}(\mathrm{II})$ complex in catalytic amount in isopropanol in the presence of different bases such as $\mathrm{NaOH}, \mathrm{KOH}, \mathrm{KOBu}-\mathrm{t}$ and $\mathrm{Na}_{2} \mathrm{CO}_{3}$. Among the bases used, $\mathrm{KOH}$ had been shown to have the best conversions. For this reason, it was decided that the base $\mathrm{KOH}$ was the best choice between the optimum reaction rates in isopropanol and that it provides 98\% conversion to benzophenone in 8 hours. In the same experimental condition, a number of substituents aromatic ketone had been investigated as $\mathrm{Ru}(\mathrm{II})$ complex catalyst via of the transfer hydrogenation. With the optimal reaction conditions in hand, we started to expand the scope and efficiency of this methodology. It had been observed that the catalytic activity varies with the substituent in the ketones. The electron donor substituent in the extracts showed a significant effect on the catalytic activity. Pentamethylacetophenone and 4-methoxyacetophenone, conversion to the corresponding alcohols was $96 \%$ and 91\%, respectively (entries 4 and 5, Table 1 ). The substrate containing electron-withdrawing substituents such as $\mathrm{Cl}, \mathrm{Br}$, plays a role at the same level of hematogenesis on conversion of ketones to alcohols (entries 2, 3 and 6, Table 1) and was catalyzed with $92 \%, 94 \%$ and $96 \%$ good conversions, respectively. Under optimized conditions, was seen when the highest conversion with 98\% benzophenone was used (entry 5, Table 1). This complex catalyzes the reduction of ketones to the corresponding alcohols when used to tertiary butylcyclohexanone and acetophenone shows less conversion of $64 \%$ and $79 \%$ respectively (entries 1, 6, Table 1). Both electron withdrawing and releasing groups with acetophenon afforded the corresponding alcohols with high yields (Table 1). It was found that present $\mathrm{Ru}(\mathrm{II})$ complex exhibited higher conversions and yields for HT.

We have tried for the ability of the catalyst for optimization of coupling reaction between phenylboronic acid and 4-bromoacetophenone with different solvents, bases and at different temperatures $\left(80,90\right.$ and $\left.100{ }^{\circ} \mathrm{C}\right)$ (Table 2). The effect of bases $\left(\mathrm{NaOH}, \mathrm{Na}_{2} \mathrm{CO}_{3}, \mathrm{~K}_{2} \mathrm{CO}_{3}, \mathrm{KOBu}^{\mathrm{t}}\right)$, solvents (DMF, 1,4-dioxane, ethanole, toluene) and reaction times were summarized (Table 2). Among the bases, $\mathrm{K}_{2} \mathrm{CO}_{3}$ was found to be the most effective. The effect of solvents was studied under the optimum conditions, using the solvents toluene, DMF, 1,4-dioxane and ethanole. Ethanole was found to be the best solvent which gave conversions in excess of $92 \%$ in $3 \mathrm{~h}$ and $80{ }^{\circ} \mathrm{C}$ as the reaction temperature (entry 6, Table 2).

The presence of electron withdrawing or electron donating substituent on groups on the aryl bromide (entries 1 and 5, Table 3) afforded the corresponding products with high yields. The best results were obtained when carbonyl groups containing aryl bromides such as 4bromoacetophenon (entry 1, Table 3) and 4bromobenzaldehyde (entry 5, Table 3) were used. Respectively 92-86\% conversion was reached within 3 hour for two substrates. Comparing the efficiency of the others aryl halides as electron donating (such as; $-\mathrm{OCH}_{3}$, $\mathrm{CH}_{3}$ ) substrates in this reaction reveals that the good results were obtained when 4bromoanisole and 4-bromotoluene were used (entries 2 and 3, Table 3) and the moderate result is obtained when bromobenzene was used as substrate (entry 4, Table 3). Using relatively electron-rich aryl bromides increased down the rate of reaction (entries 1 and 5, Table 
DEU FMD 21(61), 73-82, 2019

3 ), with the poorest results $76 \%$ conversion obtained when 4-bromobenzene was used as substrate (entry 5, Table 3). The Pd(II) complex also showed tolerance for electron withdrawing and electron donating substituents on the aryl bromide. It was found that present catalyst exhibited higher conversions and yields [36,37].

\section{Conclusion}

Four new complexes with tridentate Schiff base ligand were synthesized and characterized by physio-chemical analysis. As expected, Fe(II), $\mathrm{Zn}(\mathrm{II}), \mathrm{Ru}(\mathrm{II})$ complexes acquired a octahedral geometry coordinating via deprotonated hydroxyl oxygen, azomethine nitrogen and oxygene atoms of hydration water molecules of ligand. Pd(II) complex adopted square planar geometry by coordinating via deprotonated hydroxyl oxygen, azomethine nitrogen of ligand to the palladium centre and sulfur atoms remain unligated. The palladium complex showed good catalytic activity towards Suzuki reaction. Ru(II) complex showed efficient catalytic property for oxidation of both primary and secondary alcohols to the corresponding carbonyl compounds in the presence of $\mathrm{KOH}$ base in isopropanol, and also for transfer hydrogenation of substitued aromatic ketones with high conversions.

\section{Acknowledgments}

We are grateful to the Scientific Research-Publications and Projects Research and Practice Center (BAYPUAM) under research project no MȘÜ15-FEF-G01 of the Mus Alparslan University.

\section{References}

[1] Buldurun, K., Turan N., Savcl A., Çolak N. 2018. Synthesis, structural characterization and biological activities of metal(II) complexes with Schiff bases derived from 5-bromosalicylaldehyde: $\mathrm{Ru}(\mathrm{II})$ complexes transfer hydrogenation, Journal of Saudi Chemical Society, doi: https://doi.org/10.1016/j.jscs. 2018.06.002 (in press)

[2] Manikandan, R., Viswanathamurthi, P. Muthukumar, M. 2011. Ruthenium(II) hydrazone Schiff base complexes: Synthesis, spectral study and catalytic applications, Spectrochim Acta A Mol Biomol Spectrosc., Vol. 83, 297-303 pp. DOI: $10.1016 /$ j.saa.2011.08.033

[3] Belal, A.A.M., El-Deen, I.M., Farid, N.Y., Zakaria, R., Refat, M.S. 2015. Synthesis, spectroscopic, coordination and biological activities of some transition metal complexes containing ONO tridentate Schiff base ligand, Spectrochimica Acta Part A: Molecular and Biomolecular Spectroscopy, Vol. $149, \quad 771-787 \quad$ pp. DOI: 10.1016/j.saa.2015.05.005
[4] Orojloo, M., Zolgharnein, P., Solimannejad, M., Amani, S. 2017. Synthesis and characterization of cobalt(II), nickel(II), copper(II) and zinc(II) complexes derived from two Schiff base ligands: Spectroscopic, thermal, magnetic moment, electrochemical and antimicrobial studies, Inorganica Chimica Acta, Vol. 467, 227-237 pp. DOI:10.1016/j.ica.2017.08.016

[5] De Araújo, E.L., Barbosa, H.F.G., Dockal, E.R., Cavalheiro, T.G. 2017. Synthesis, characterization and biological activity of $\mathrm{Cu}(\mathrm{II}), \mathrm{Ni}(\mathrm{II})$ and $\mathrm{Zn}(\mathrm{II})$ complexes of biopolymeric Schiff bases of salicylaldehydes and chitosan, International Journal of Biological Macromolecules, Vol. 95, 168176 pp.DOI:10.1016/j.ijbiomac.2016.10.109

[6] Modha, S.G., Mehta, V.P., Van der Eycken, E.V. 2013. Transition metal-catalyzed C-C bond formation via C-S bond cleavage: an overview, Chemical. Society. Reviews, Vol. 42, 5042-5055 pp. DOI: $10.1039 / \mathrm{c} 3 \mathrm{cs} 60041 \mathrm{f}$.

[7] Pal, S. Hwang, W.S. Lin, I.J.B., Lee, C.S. 2007.Benzene benzimidazole containing Pd(II) metallacycle: Synthesis, X-ray crystallographic characterization and its use as an efficient Suzuki coupling catalyst, Journal of Molecular Catalysis A: Chemical, Vol. 269, 197-203 pp. DOI:10.1016/j.molcata.2007.01.028

[8] Bian, H.D., Wang, J., Wei, Y., Tang, J., Huang, F.P., Yao, D., Yu, Q., Liang, H. 2015. Superoxide dismutase activity studies of $\mathrm{Mn}(\mathrm{III}) / \mathrm{Cu}(\mathrm{II}) / \mathrm{Ni}(\mathrm{II})$ complexes with Schiff base ligands, Polyhedron, Vol. 90, 147-153 pp. DOI:10.1016/j.poly.2015.01.022

[9] Abou-Hussein, A.A., Linert, W. 2015. Synthesis, spectroscopic studies and inhibitory activity against bactria and fungi of acyclic and macrocyclic transition metal complexes containing a triamine coumarine Schiff base ligand, Spectrochimica Acta Part A: Molecular and Biomolecular Spectroscopy, Vol. $\quad 141, \quad 223-232$ DOI:10.1016/j.saa.2015.01.063

[10] Roy, N., Sproules, S., Bothe, E., Weyhermüller, T., Wieghardt, K. 2009. Polynuclear Complexes containing the redox noninnocent Schiff base ligand 2-[(E)-2-mercaptophenylimino]methyl-4,6di-tert-butylphenolate(2-), European Journal of Inorganic Chemistry, Vol. 2009, 2655-2663 pp. DOI: $10.1002 /$ ejic.200900168

[11] Gupta, K.C., Sutar, A.K, 2008. Catalytic activity of Schiff base complexes, Coordination Chemistry Reviews, Vol. 252, 1420-50 pp.DOI:10.1016/j.ccr.2007.09.005

[12] Islam, S.M., Mondal, P., Roy, A.S., Mondal, S., Hossain, D. 2010. Heterogeneous Suzuki and copper-free Sonogashira cross-coupling reactions catalyzed by a reusable palladium(II) complex in water medium, Tetrahedron Letter, Vol. 51, 20672070 pp. DOI:10.1016/j.tetlet.2010.02.079

[13] Diederich, F., Stang, P.J. 1998. Metal catalyzed cross-coupling reactions, Wiley-VCH, Weinheim. Vol. 878, 12 pp. DOI: 10.1002/(SICI)1099-0739(199812)

[14] Bakherad, M., Keivanloo, A., Amin, A.H., Jajarmi S. 2012. Phosphine-free polystyrene-supported palladium(II) complex as anefficient catalyst for 
DEU FMD 21(61), 73-82, 2019

the Heck and Suzuki coupling reactions in water Comptes Rendus Chimie, Vol. 15, $945-949$ pp. DOI:10.1016/j.crci.2012.06.009

[15] Rao, G.K., Kumar, A., Bhunia, M., Singh, M.P., Singh, A.K. 2014. Complex of 2-(methylthio)aniline with palladium(II) as an efficient catalyst for SuzukiMiyaura C-C coupling in eco-friendly water, Journal of Hazardous Materials, Vol. 269, 18-23 pp. DOI: 10.1016/j.jhazmat.2013.11.045

[16] Navidi, M., Rezaei, N., Movassagh, B. 2013.Palladium(II)-Schiff base complex supported on multi-walled carbon nanotubes: A heterogeneous and reusable catalyst in the SuzukiMiyaura and copper-free Sonogashira-Hagihara reactions, Journal of Organometallic Chemistry, Vol. 743 63-69 DOI:10.1016/j.jorganchem.2013.06.021

[17] Albayrak Kas, C.., Kas, G., Güder, A., Gür, M., Muğlu, H., Büyükgüngör, 0. 2017. Investigation of two ohydroxy Schiff bases in terms of prototropy and radical scavenging activity, Journal of Molecular Structure, Vol. 1130, 623-632 pp. DOI:10.1016/j.molstruc.2016.11.023

[18] Mieczyn'ska, E., Lisowski, J., Trzeciak, A.M. 2015. A macrocyclic Pd(II)-Ni(II) complex in Heck and Suzuki reactions, Inorganica Chimica Acta, Vol. 431, 145-149 pp. DOI:10.1016/j.ica.2014.11.008

[19] Kantam, M.L., Annapurna, V., Likhar, P.R., Srinivas, P., Mirzadeh, V., Bhargava, S.K. 2013. Palladium complexes containing multidentate phenoxyepyridyleamidate ligands: Highly efficient catalyst for Heck coupling of deactivated aryl halides, Journal of Organometallic Chemistry, Vol 723, 129-136 DOI:10.1016/j.jorganchem.2012.08.037

[20] Park, S.B., Alper, H, 2003. Highly efficient, recyclable $\mathrm{Pd}(\mathrm{II})$ catalysts with bisimidazole ligands for the heck reaction in ionic liquids, Organic Letter, Vol. 5, 3209-3212 pp. DOI: $10.1021 /$ ol030071d

[21] Anan, N.A., Hassan, S.M., Saad, E.M., Butler, I.S., Mostafa, S.I. 2011. Preparation, characterization and pH-metric measurements of 4hydroxysalicylidenechitosan Schiff-base complexes of Fe(III), Co(II), Ni(II), Cu(II), Zn(II), Ru(III), $\mathrm{Rh}(\mathrm{III}), \mathrm{Pd}(\mathrm{II})$ and Au(III), Carbohydrate Research, Vol. 346,775-793 DOI:10.1016/j.carres.2011.01.014

[22] Kundu, S., Pramanik, A.K., Mondal, A.S., Mondal, T.K. 2016. Ni(II) and Pd(II) complexes with new $\mathrm{N}, \mathrm{O}$ donor thiophene appended Schiff base ligand: Synthesis, electrochemistry, X-ray structure and DFT calculation, Journal of Molecular Structure, Vol.

$$
1116,1-8
$$

DOI:10.1016/j.molstruc.2016.03.013

[23] Barbu, L., Popa, M.M., Shova, S., Ferbinteanu, M Draghici, C.,Dumitrascu, F. 2017.New Pd-NHC PEPPSI complexes from benzimidazolium salts with a phenacyl group attached to N3, Inorganica Chimica Acta, Vol. 463,97-101 pp. DOI: 10.1016/j.ica.2017.04.024

[24] Agrahari, B., Layek, S., Ganguly Anuradha, R., Pathak, D.D. 2018. Synthesis crystal structures and application of two new pincer type palladium(II)Schiff base complexes in C-C cross-coupling reactions, Inorganica Chimica Acta, Vol. 471, 345$354 \mathrm{pp}$. DOI:10.1016/j.ica.2017.11.018

[25] Wang, L., Yang, Q., Chen, H., Li, R.X, 2011. A novel cationic dinuclear ruthenium complex: Synthesis,characterization and catalytic activity in the transfer hydrogenation of ketones, Inorganic Chemistry Communications, Vol. 14, 1884-1888 pp. DOI:10.1016/j.inoche.2011.09.003

[26] Sece, J.M., Quiros, M., Garmendina, M.J.G, 2000. Synthesis, X-ray crystal structure and spectroscopic, magnetic and EPR studies of copper(II) dimers with methoxy-di-(2pyridyl)methoxide as bridging ligand, Polyhedron, Vol. 19, 1005-1013 pp. PII S0277-5387(0 0)003569

[27] Dehkhodaei, M., Khorshidifard, M., Rudbari, H.A., Sahihi, M., Azimi, G., Habibi, N., Taheri, S., Bruno, G., Azadbakht, R. 2017. Synthesis, characterization, crystal structure and DNA, HSA-binding studies of four Schiff base complexes derived from salicylaldehyde and isopropylamine, Inorganica Chimica Acta, Vol. 466, 48-60 pp. DOI: $10.1016 /$ j.ica.2017.05.035

[28] Tamizh, M.M., Cooper, B.F.T., Macdonald, C.L.B., Karvembu, R. 2013. Palladium(II) complexes with salicylideneimine based tridentate ligand and triphenylphosphine: Synthesis, structure and catalytic activity in Suzuki-Miyaura cross coupling reactions, Inorganica Chimica Acta, Vol. 394, 391400 pp. DOI: 10.1016/j.ica.2012.08.024

[29] Nithya, P., Simpson, J., Govindarajan, S. 2017. Template synthesis, structural variation, thermal behavior and antimicrobial screening of Mn(II), Co(II) and Ni(II) complexes of Schiff base ligands derived from benzyl carbazate and three isomers of acetylpyridine, Inorganica Chimica Acta, Vol. 467, 180-193 pp. DOI:10.1016/j.ica.2017.07.059

[30] Anupama, B., Sunita, M., Shiva Leela, D., Ushaiah, B., Gyana Kumari, C. 2014. Synthesis, spectral characterization, DNA binding studies and antimicrobial activity of Co(II), Ni(II), Zn(II), Fe(III) and VO(IV) complexes with 4-aminoantipyrine Schiff base of ortho-vanillin,Journal of Fluorescence, Vol. 24, 1067-1076 pp. DOI: 10.1007/s10895-014-1386-z

[31] Abdel-Rahman, L.H., Abu-Dief, A.M., Newair, E.F., Hamdan, S.K. 2016. Some new nano-sized Cr(III), $\mathrm{Fe}(\mathrm{II}), \mathrm{Co}(\mathrm{II})$, and $\mathrm{Ni}(\mathrm{II})$ complexes incorporating 2-((E)-(pyridine-2-ylimino)methyl)napthalen-1-ol ligand: Structural characterization, electrochemical, antioxidant, antimicrobial, antiviral assessment and DNA interaction, Journal of Photochemistry \& Photobiology, B: Biology, Vol. 160, 18-31 pp. DOI:10.1016/j.jphotobiol.2016.03.040

[32] Shabbir, M., Akhter, Z., Ashraf, A.R., Ismail, H., Habib, A., Mirza, B. 2017. Journal nickel(II) and palladium(II) triphenylphosphine complexes incorporating tridentate Schiff base ligands: Synthesis, characterization and biocidal activities, Journal of Molecular Structure, Vol. 1149, 720-726 pp. DOI:0.1016/j.molstruc.2017.08.050

[33] Odabasoglu, M., Arslan, F., Olmez, H., Buyukgungor, 0., 20007. Synthesis, crystal structures and 
DEU FMD 21(61), 73-82, 2019

spectral characterization of trans-bisaquabis(ovanillinato)copper(II), cis-aquabis(ovanillinato)copper(II) and aqua[bis(o-vanillinato)1,2-ethylenediimin]copper(II), Dyes Pigm., Vol. 75, 507-515 pp.

DOI: 10.1016/j.dyepig.2006.06.033

[34] Anan, N.A., Hassan, S.M., Saad, E.M., Butler, I.S., Mostafa, S.I. 2011. Preparation, characterization and pH-metric measurements of 4hydroxysalicylidenechitosan Schiff-base complexes of $\mathrm{Fe}(\mathrm{III}), \mathrm{Co}(\mathrm{II}), \mathrm{Ni}(\mathrm{II}), \mathrm{Cu}(\mathrm{II}), \mathrm{Zn}(\mathrm{II}), \mathrm{Ru}(\mathrm{III})$ Rh(III), Pd(II) and Au(III), Carbohydrate Research, Vol. 346, 775-793 pp.

DOI: 10.1016/j.carres.2011.01.014

[35] Mohamed, G.G., Omar, M.M., Hindy Ahmed, M.M. 2005. Synthesis, characterization and biological activity of some transition metals with Schiff base derived from 2-thiophene carboxaldehyde and aminobenzoic acid, SpectrochimicaActa Part A: Molecular and Biomolecular Spectroscopy, Vol. 62, 1140-1150 pp.

DOI: 10.1016/j.saa.2005.03.031

[36] Kalita, M., Tamuli, K.J., Barman, P., Sarma, B., Baruah, R., Boruah, H.P.D. 2015. Synthesis, crystal structure, bioactivities of $\mathrm{Ni}(\mathrm{II}), \mathrm{Cu}(\mathrm{II}), \mathrm{Co}(\mathrm{II})$ and Pd(II) complexes with unsymmetrical thioether donor Schiff base: Phosphine free Pd(II) complex catalyzed Suzuki reaction, Polyhedron, Vol. 97, 140-147 pp. DOI:10.1016/j.poly.2015.05.020

[37] Gholinejad, M., Shahsavari, H.R.2014. N,N'-bis(2pyridinecarboxamide)-1,2-benzene palladium complex as a new efficient catalyst for SuzukiMiyaura coupling reaction under phosphane free conditions, Inorg. Chim. Acta, Vol. 421, 433-438 pp. DOI:10.1016/j.ica.2014.06.039 